\title{
Pulmonary Neuroendocrine Cells in Hyaline Membrane Disease and Bronchopulmonary Dysplasia
}

\author{
DANA E. JOHNSON, ${ }^{(38)}$ JAMES E. LOCK, ROBERT P. ELDE, THEODORE R. THOMPSON \\ Departments of Pediatrics and Anatomy, University of Minnesota Medical School, Minneapolis, Minnesota, USA
}

\begin{abstract}
Summary
The number and distribution of bombesin immunoreactive pulmonary neuroendocrine cells (PNEC) in fetuses and infants up to 6 months of age was determined on postmortem lung specimens. Individual cells and clusters of cells (neuroepithelial bodies) were found in airways of all sizes, although greater than $95 \%$ of the positive cells were located in bronchioles, terminal bronchioles, and respiratory bronchioles. These infants were separated into two groups. In control infants, who died primarily from noncardiopulmonary causes, bombsin immunoreactive neuroendocrine cells were identified throughout the latter half of gestation. As gestation advanced, progressively more positive bronchioles $/ \mathrm{cm}^{2}$ of lung tissue and cells/bronchiole were identified. In these control infants, the number of positive bronchioles $/ \mathrm{cm}^{2}$ and cells/bronchiole were at the highest level at or near the time of delivery and then gradually declined throughout the first 6 months of life. In contrast, infants who died of acute hyaline membrane disease (1-7 days of life) or bronchiopulmonary dysplasia ( 2 wk to 6 months of life) demonstrated marked differences in the number of identifiable bombesin immunoreactive neuroendocrine cells when compared to control infants. In early hyaline membrane disease, the number of positive bronchioles $/ \mathrm{cm}^{2}$ and cells/bronchiole was markedly decreased. During the transition to chronic bronchopulmonary dysplasia, there appeared to be a marked increase in the number of bombesin immunoreactive cells. The peak number of cells occurred at 2-3 months of life, when substantially more bombesin-immunoreactive cells could be identified in children with bronchopulmonary dysplasia than control infants of similar age.
\end{abstract}

\section{Speculation}

This study demonstrates that a specific pulmonary cell type containing bioactive molecules undergoes marked changes during acute and chronic neonatal lung disease. Anatomic and physiologic evidence suggests that these cells may be in an ideal position to exert control on pulmonary vessel and airway tone either at the local level or throughout the entire lung through vascular and neural connections. These data do not prove that alterations in this cell population are the cause of changes noted in airway and in vascular resistance in infants with lung disease. They do identify, however, a new area of potential investigation in these disease states.

A distinct population of granulated cells posessing both endocrine and neural characteristics has been recognized in the respiratory epithelium for over thirty years $(8,10)$. These pulmonary neuroendocrine cells (PNEC) are identified in greatest numbers during the neonatal period $(19,24)$ and are situated near both pulmonary vessels and nerves $(8,10,20,23,28)$.

Recent work has demonstrated that the secretory granules of these cells contain biologically active molecules such as serotonin (18), as well as peptides with bombesin (36) and calcitonin im- munoreactivity (2). Bombesin, a 14 amino acid peptide, is a member of the continually expanding family of peptides found in both the gut and the brain. This peptide is an active molecule known to affect smooth muscle contraction of a number of organ systems, including the lung $(3,15,34,35)$.

The functional importance of these cells is undefined, but preliminary evidence has suggested that PNEC may be chemoreceptors contributing to the control of pulmonary vascular and/or airway tone in response to alterations in airway gas composition $(20,21,24,32)$. Despite their abundance in the neonatal lung, little is known regarding the effect of acute and chronic neonatal lung disease on these PNEC. The purpose of this study is to describe the changes in the number of bombesin-immunoreactive PNEC in two common neonatal pulmonary disorders where alterations in both pulmonary aeration and perfusion are known to occur: hyaline membrane disease (HMD) and chronic bronchopulmonary dysplasia (BPD).

\section{MATERIALS AND METHODS}

Subjects. Sixty-two hospitalized infants who died at the University of Minnesota Hospitals from 1956 through 1980 were used as the study population. Their ages at the time of death ranged from birth to 6 months of age. Twenty-six of these infants had acute HMD or BPD (Table 1). These 26 patients had required mechanical ventilation and supplemental oxygen for most or all of their lives. The diagnosis of both HMD and BPD were pathologically confirmed (29). Thirty-six fetuses and infants who died primarily from noncardiopulmonary causes were used as the control population (Table $2 a$ and $1 b$ ). Although a number of these infants had required short term mechanical ventilation before death, none showed pathologic evidence of ventilator or oxygen toxicity to the lung. This study was approved by the Committee on the Use of Human Subjects in Research at the University of Minnesota Medical School.

Tissue selection. Formalin-fixed, paraffin-embedded lung specimens were obtained from the University of Minnesota Hospitals Pathology file for each of the above infants. Autopsies had been conducted in all cases within $24 \mathrm{~h}$ of death. An average of 2.07 \pm 0.75 (S.D.) randomly chosen tissue blocks were examined per patient. The precise region of the lung from which tissue was taken was known for only a minority of specimens. Six patients had only one tissue block available for study.

Immunohistochemistry. The localization of bombesin imunoreactivity was accomplished on $5 \mu$ tissue sections using the unlabeled antibody-peroxidase-antiperoxidase technique of Sternberger, et al. (31) Rabbit antibombesin (Immunonuclear Corp., Stillwater, $\mathrm{MN}$ ), raised in response to a synthetic amphibian bombesin, was used at a dilution of 1:200 in phosphate buffered saline (PBS) (pH 7.2) with 0.5\% Triton X-100 (Research Products International, Elk Grove Village, IL). Sections mounted on gelatin coated slides were incubated overnight at $3^{\circ}$ with the primary antiserum. Sections were then incubated sequentially for $l \mathrm{~h}$ at 
Table 1. Clinical data on infants with respiratory distress syndrome and bronchopulmonary dysplasia

\begin{tabular}{|c|c|c|c|c|}
\hline $\begin{array}{l}\text { Age at } \\
\text { death }\end{array}$ & $\begin{array}{c}\text { Birth } \\
\text { weight }\end{array}$ & Gestational age & $\begin{array}{l}\text { Mechani- } \\
\text { cal } \\
\text { ventilation }\end{array}$ & $\begin{array}{l}\text { Oxygen } \\
\text { requirements }\end{array}$ \\
\hline \multirow{3}{*}{1 day } & $1490 \mathrm{~g}$ & $30 \mathrm{wk}$ & 1 day & 1 day \\
\hline & $920 \mathrm{~g}$ & 27 wk & 1 day & 1 day \\
\hline & $1790 \mathrm{~g}$ & $36 \mathrm{wk}$ & I day & 1 day \\
\hline \multirow{3}{*}{3 days } & $1455 \mathrm{~g}$ & 32 wk & 3 days & 3 days \\
\hline & $2200 \mathrm{~g}$ & $34 \mathrm{wk}$ & 3 days & 3 days \\
\hline & $3460 \mathrm{~g}$ & $36 \mathrm{wk}^{1}$ & 3 days & 3 days \\
\hline \multirow{3}{*}{7 days } & $1200 \mathrm{~g}$ & $28 w k$ & 7 days & 7 days \\
\hline & $1400 \mathrm{~g}$ & $32 \mathrm{wk}$ & 7 days & 7 days \\
\hline & $1750 \mathrm{~g}$ & $31 \mathrm{wk}$ & 7 days & 7 days \\
\hline \multirow{3}{*}{$2 \mathrm{wk}$} & $1500 \mathrm{~g}$ & $30 \mathrm{wk}$ & $2 \mathrm{wk}$ & $2 \mathrm{wk}$ \\
\hline & $3740 \mathrm{~g}$ & $40 \mathrm{wk}^{2}$ & $2 \mathrm{wk}$ & $2 \mathrm{wk}$ \\
\hline & $1420 \mathrm{~g}$ & $30 \mathrm{wk}$ & $2 \mathrm{wk}$ & $2 \mathrm{wk}$ \\
\hline \multirow{3}{*}{3 wk } & $1500 \mathrm{~g}$ & $32 \mathrm{wk}$ & $3 \mathrm{wk}$ & 3 wk \\
\hline & $1290 \mathrm{~g}$ & $30 \mathrm{wk}$ & $3 \mathrm{wk}$ & 3 wk \\
\hline & $1600 \mathrm{~g}$ & $35 \mathrm{wk}$ & $3 \mathrm{wk}$ & 3 wk \\
\hline \multirow{3}{*}{2 months } & $1400 \mathrm{~g}$ & $29 \mathrm{wk}$ & 2 months & 2 months \\
\hline & $2000 \mathrm{~g}$ & $32 \mathrm{wk}$ & 2 months & 2 months \\
\hline & $1800 \mathrm{~g}$ & 23 wk & $5 w^{3}$ & 2 months \\
\hline \multirow{3}{*}{3 months } & $1800 \mathrm{~g}$ & $34 \mathrm{wk}$ & 3 months & 3 months \\
\hline & $1430 \mathrm{~g}$ & $32 \mathrm{wk}$ & 3 months & 3 months \\
\hline & $1093 \mathrm{~g}$ & $32 \mathrm{wk}$ & 3 months & 3 months \\
\hline \multirow{3}{*}{4 months } & $1020 \mathrm{~g}$ & $32 \mathrm{wk}$ & Last $6 \mathrm{wk}$ & Last 6 wk \\
\hline & $2650 \mathrm{~g}$ & $36 \mathrm{wk}$ & $3 \mathrm{wk}$ & 4 months \\
\hline & $1450 \mathrm{~g}$ & $30 \mathrm{wk}$ & $6 \mathrm{wk}$ & 4 months \\
\hline \multirow{2}{*}{6 months } & $1030 \mathrm{~g}$ & $30 \mathrm{wk}$ & 6 months & 6 months \\
\hline & $1956 \mathrm{~g}$ & $32 \mathrm{wk}$ & 3 months & 6 months \\
\hline
\end{tabular}

${ }^{1}$ Infant of diabetic mother.

${ }^{2}$ Meconium aspiration syndrome.

${ }^{3}$ Nasal CPAP until death.

room temperature with sheep anti-rabbit IgG (Cappel Laboratories, Cochranville, PA) diluted 1:200 in borate buffered saline $(\mathrm{pH}$ 8.5) with $1 \%$ normal sheep serum (NSS) (Antibodies, Inc., Davis, $\mathrm{CA}$ ) and rabbit peroxidase-antiperoxidase (PAP) (Cappel Laboratories, diluted 1:500 in BBS with $1 \%$ NSS).

The specificity of bombesin localization was tested by incubating varying concentrations of peptides with the primary immune sera for $1 \mathrm{~h}$ at room temperature before its application to tissue sections. Localization of bombesin-immunoreactive cells in the lung was prevented by $0.1 \mu \mathrm{g}$ of bombesin per ml diluted antisera (1:200). The addition of $50 \mu \mathrm{g}$ of litorin, eledoisin, substance $\mathrm{P}$, somatostatin, neurotensin or met-enkephalin did not prevent the staining of bombesin-immunoreactive cells in the bronchiolar epithelium. All peptides for absorption controls were obtained from Penninsula Laboratories, San Carlos, CA. No immunoreactive cells were demonstrated when nonimmune rabbit sera was substituted for the primary antibody or when BBS was substituted for sheep anti-rabbit IgG or rabbit PAP.

Quantitation. Quantitation of bombesin-immunoreactive cells in the pulmonary airways was performed to numerically confirm our histologic observations. Three-six sections per block, spaced $25 \mu$, apart, were selected and visually quantitated at $\times 100$ for cells demonstrating bombesin immunoreactivity. No attempt was made to separately quantitate single pulmonary neuroendocrine cells and bombesin-immunoreactive neuroendocrine cells in neuroepithelial bodies (NEB). In histologic sections, where delinea- tion of individual cells was difficult, only nucleated immunoreactive cells were ennumerated. Differentiation between hyperplasia of individual PNEC and hyperplasia of cells within NEB was extremely difficult using these techniques and was not attempted. Two measurements were made from each slide: (1) the total number of airways in any plane of section (cross, longitudinal, or tangenital) (Fig. 6 and 7) exhibiting bombesin-immunoreactive cells (expressed as airways $/ \mathrm{cm}^{2}$ ), and (2) the total number of

Table 2a. Control term infants-clinical data (Age at Death I day6 months)

\begin{tabular}{|c|c|}
\hline Age at death & Diagnosis \\
\hline 1 day & $\begin{array}{l}\text { Mesoblastic nephroma } \\
\text { Massive hemolysis (? etiology) } \\
\text { Massive hemolsis (G-6-PD deficiency) }\end{array}$ \\
\hline 3 days & $\begin{array}{l}\text { Myelodysplasia-gram negative sepsis } \\
\text { Renal vein thrombosis } \\
\text { Birth asphyxia }\end{array}$ \\
\hline 7 days & $\begin{array}{l}\text { Intestinal perforation-gram negative sepsis } \\
\text { Omphalocele-gram negative meningitis } \\
\text { Myelodysplasia-gram_negative sepsis }\end{array}$ \\
\hline $2 \mathrm{wk}$ & $\begin{array}{l}\text { E. coli Septicemia } \\
\text { Myelodysplasia-gram negative sepsis } \\
\text { No pathologic diagnosis (? SIDS) }\end{array}$ \\
\hline $3 \mathrm{wk}$ & $\begin{array}{l}\text { Myelodysplasia-gram negative meningitis } \\
\text { Hyperammonemia syndrome } \\
\text { Cerebral trauma }\end{array}$ \\
\hline 2 months & $\begin{array}{l}\text { Peritonitis-gram negative sepsis } \\
\text { Sudden infant death syndrome (SIDS) } \\
\text { Cerebral trauma }\end{array}$ \\
\hline 3 months & $\begin{array}{l}H . \text { Influenzae meningitis } \\
\text { Reye's syndrome }\end{array}$ \\
\hline 4 months & $\begin{array}{l}\text { Meningiococcemia } \\
\text { Lactic acidosis (? inborn error of metabolism) } \\
\text { Myelodysplasia, recurrent seizures }\end{array}$ \\
\hline 5 months & $\begin{array}{l}\text { E. coli sepsis } \\
\text { Acute subdural hematoma }\end{array}$ \\
\hline 6 months & $\begin{array}{l}\text { S. Pneumoniae meningitis } \\
\text { H. Influenzae meningitis } \\
\text { Peritonitis-gram negative sepsis }\end{array}$ \\
\hline
\end{tabular}

Table 2b. Control preterm infants-clinical data (age at death $<12$ h)

\begin{tabular}{|c|c|c|c|}
\hline & $\begin{array}{l}\text { Gestational } \\
\text { age (wk) }\end{array}$ & $\begin{array}{l}\text { Birth weight } \\
\text { (g) }\end{array}$ & $\begin{array}{l}\text { Time of death } \\
\text { (diagnosis) }\end{array}$ \\
\hline \multirow[t]{3}{*}{ Second trimester } & 19 & 200 & Stillborn \\
\hline & 23 & 477 & $\begin{array}{l}1 \mathrm{~h} \text { (Respiratory in- } \\
\text { sufficiency) }\end{array}$ \\
\hline & 25 & 590 & $\begin{array}{l}9 \mathrm{~h} \text { (Respiratory in- } \\
\text { sufficiency) }\end{array}$ \\
\hline \multirow[t]{3}{*}{ Third trimester } & 8 & 1480 & $\begin{array}{l}9 \mathrm{~h} \text { (Respiratory dis- } \\
\text { tress syndrome) }\end{array}$ \\
\hline & 32 & 1510 & Stillborn \\
\hline & 34 & 1800 & $\begin{array}{l}5 \mathrm{~h} \text { (Respiratory dis- } \\
\text { tress syndrome) }\end{array}$ \\
\hline \multirow[t]{2}{*}{ Term delivery } & 38 & 2727 & $\begin{array}{l}6 \mathrm{~h} \text { (Birth trauma, as- } \\
\text { phyxia) }\end{array}$ \\
\hline & 40 & 3560 & Stillborn \\
\hline
\end{tabular}


bombesin-immunoreactive cells airway (expressed as cells/airway). In order to simplify comparison between patients for the second measurement, the total number of immunoreactive cells were counted only in true cross sections of individual airways $\left(90^{\circ}\right)$ (Fig. 6 and 7 ). These two values provided a semi-quantitative index useful in numerically comparing the total number of positive cells per unit of lung tissue in control infants and infants with RDS and BPD. Three categories of airways were quantitated separately: cartilagenous bronchi, bronchioles, and terminal airways (alveolar ducts through alveoli). Traced outlines were used to determine the area of each tissue section either by gravametric means or by using a Hewlett-Packard (Fort Collins, CO) 9845B computer with a $9874 \mathrm{~A}$ digitizer. The average area quantitated per infant was $7.95 \pm 4.35$ (S.D.) $\mathrm{cm}^{2}$.

\section{RESULTS}

General anatomic observations. In both control infants and those with lung disease, individual bombesin-immunoreactive cells and clusters of cells (neuroepithelial bodies) were localized in all sizes of intrapulmonary airways (bronchi through alveolar ducts). Individual cells were cylindrical, reaching from the basement membranes to near the airway lumen (Fig. 1). The majority of immunoreactivity within a cell was located at the basal pole of the cell (Fig. 1).

Cell bodies were often encountered exhibiting attenuated processes which extended between the basement membrane and adjacent cells (Fig. 2). These cells were more frequently encountered or apparent in infants with BPD. Immunoreactive neuroepithelial bodies were often seen at the bifurcation of airways (Fig. 3 ). Although immunoreactive cell bodies were localized in all sizes of intrapulmonary airways, greater than $95 \%$ of the immunoreactive cells were located in bronchioles, terminal bronchioles, and respiratory bronchioles. Since the overwhelming majority of positive cells were found in the bronchioles, the remainder of our results will deal specifically with these airways.

Control infants. Immunoreactive cells were easily identified throughout the latter half of gestation, even in the youngest fetus

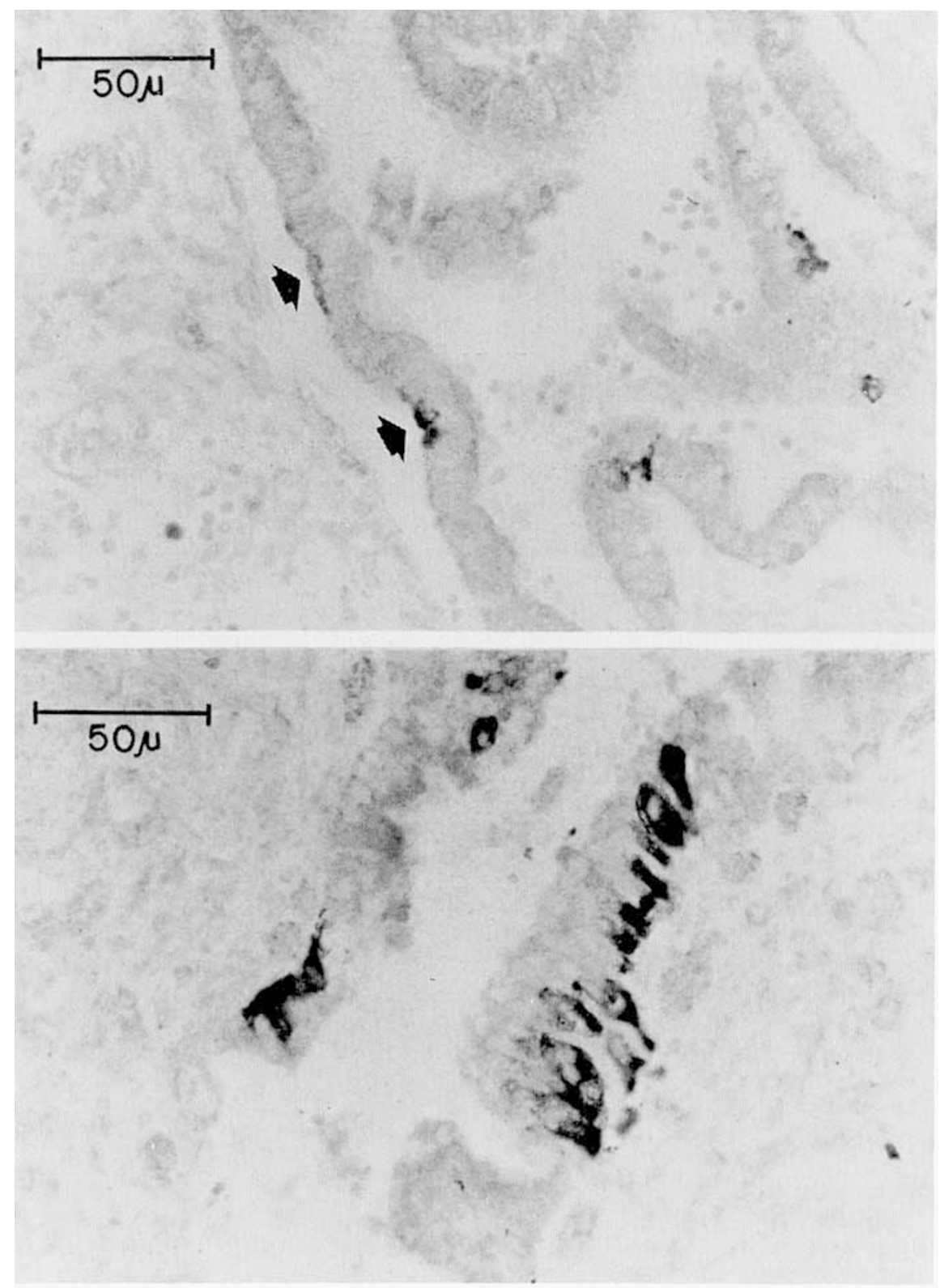

Fig. 1. Bombesin immunoreactive pulmonary neuroendocrine cells (PNEC) (dark staining cells) within the bronchiolar epithelium. TOP: PNEC in an infant dying at 3 days of age with respiratory distress syndrome. The cells appear to be degranulated as bombesin immunoreactivity is decreased and is marginated at the extreme basal pole of the cell (arrows). Separation of the epithelium is a postmortem change. BOTTOM: PNEC in an infant dying at 2 months of age with bronchopulmonary dysplasia. The cells stain densely with the majority of immunoreactivity basally located. 

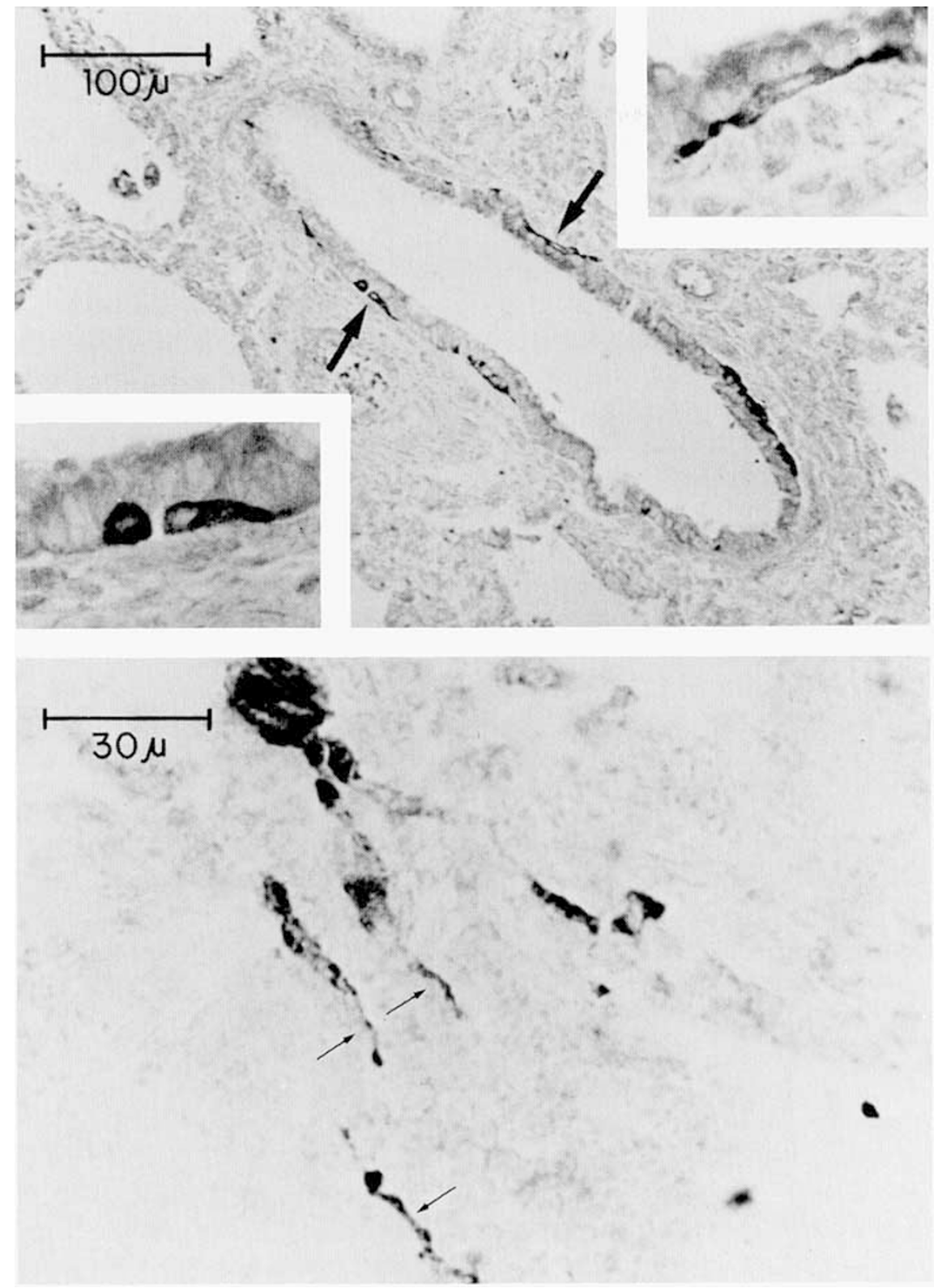

Fig. 2. Pulmonary neuroendocrine cells (PNEC) in infants dying at $3 \mathrm{wk}$ of age. TOP: the secrion through the bronchiole demonstrates PNEC with filamentous processes (arrows) extending between adjacent epithelial cells and the basement membrane. BOTTOM: a tangenital cut through the epithelium of a bronchiole near the basement demonstrates the interdigitating filamentous processes (arrows) of PNECs extending toward adjacent epithelial cells.

studied (19 wk gestation, 200 g) (Fig. 3, top). As gestation advanced, progressively more positive bronchioles $/ \mathrm{cm}^{2}$ and cells/ bronchiole were identified (Fig. 4-5). In control infants, most of whom were born at term, the number of positive bronchioles $/ \mathrm{cm}^{2}$ and cells/bronchiole were at the highest point at or near the time of delivery (Fig. 4-7). Both of these parameters decline gradually throughout the first months of life.

Infants with lung disease. Infants who died of HMD (1-7 days of life) or BPD (2 wk-6 months of life) demonstrated a marked difference in the number of identifiable bombesin-immunoreactive cells compared to control patients. During the acute course of HMD, where the degree of pathologic changes correlated with stage 1 (3 days) and 2 (7 days) of Rosan (29), the number of immunoreactive bronchioles $/ \mathrm{cm}^{2}$ and immunoreactive cells/bronchioles was markedly decreased (Fig. 4 -5). Infants with HMD had the majority of their granularity located near the basement membrane, as opposed to control infants where the immunoreactivity was dispersed more homogenously throughout the cell. Therefore, histologically, the decrease in immunoreactivity noted during this first wk of life in infants with HMD appeared to be a continuum of degranulation and cell loss (Fig 1, top; Fig 6). After this acute initial loss of immunoreactivity and epithelial necrosis, there was a gradual increase in immunoreactive cells correlating with the regeneration and hyperplasia of bronchiolar epithelial cells (Stage 3-4 BPD) (29). The peak number of cells occurred at 2-3 months of life (Stage 4 BPD), when substantially more cells were demonstrated in children with BPD than in controls of similar age (Fig. 4, 5, 7). Infants with HMD or BPD differed significantly not only from the values seen in control infants, but from values obtained during gestation.

\section{DISCUSSION}

Pulmonary neuroendocrine cells have been referred to by many other names: Pulmonary Helle Zelle (10), Feyrter cells (26), Kultschitzky cells $(2,23)$, AFG cells (17), enterochromaffin cells (6), APUD cells (5), pulmonary endocrine-like cells (13), and pulmonary neurosecretory cells (33). Individual cells, identified by classic 

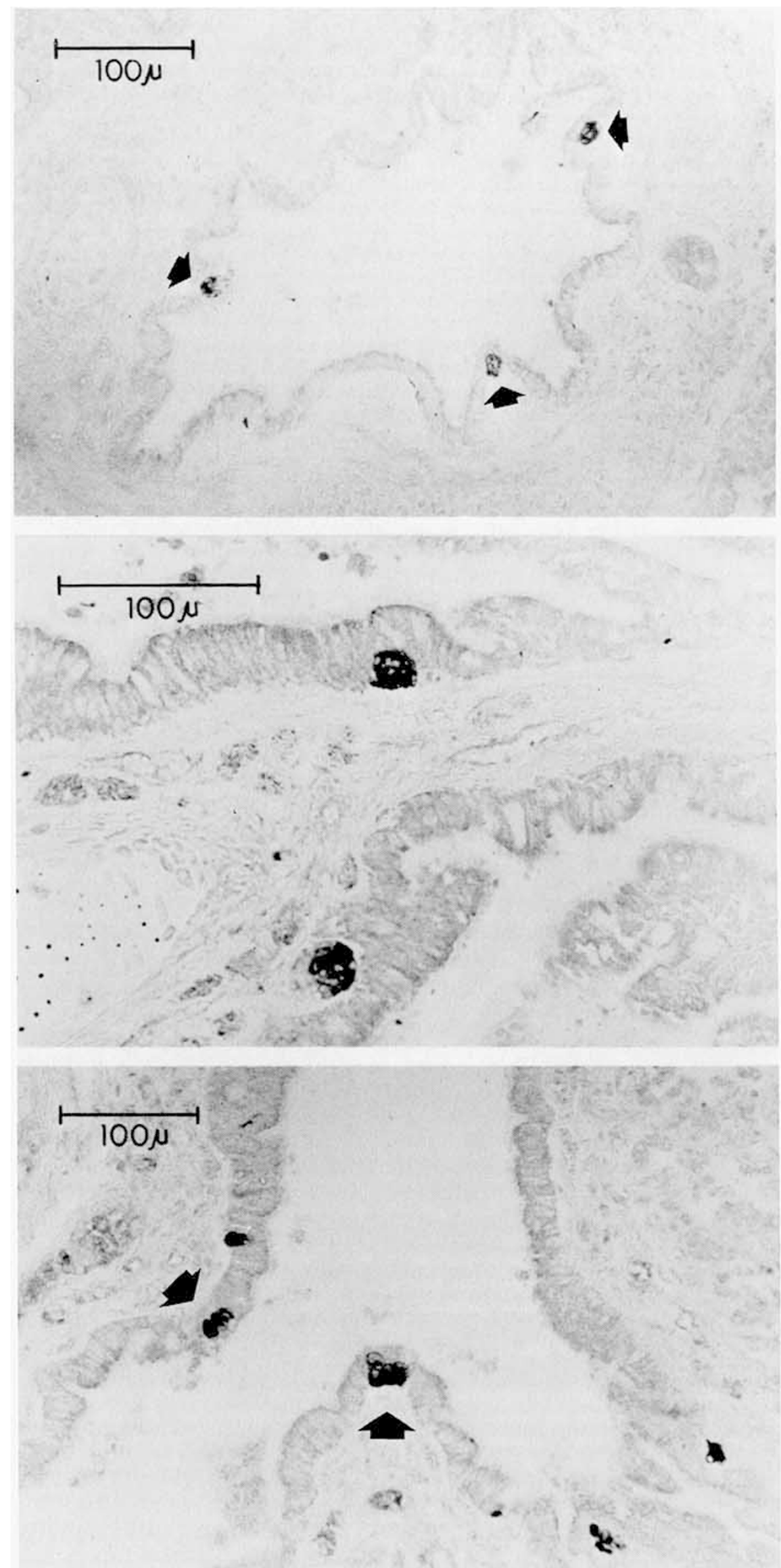

Fig. 3. TOP: clusters of bombesin-positive neuroendocrine cells (neuroepithelial bodies) (arrows) in a bronchus of a 19-wk fetus. MIDDLE: neuroepithelial bodies in bronchi of a 3-wk infant dying with BPD.
BOTTOM: neuroepithelial bodies (arrows) at bifurcation of a bronchiole in a stillborn term infant. 


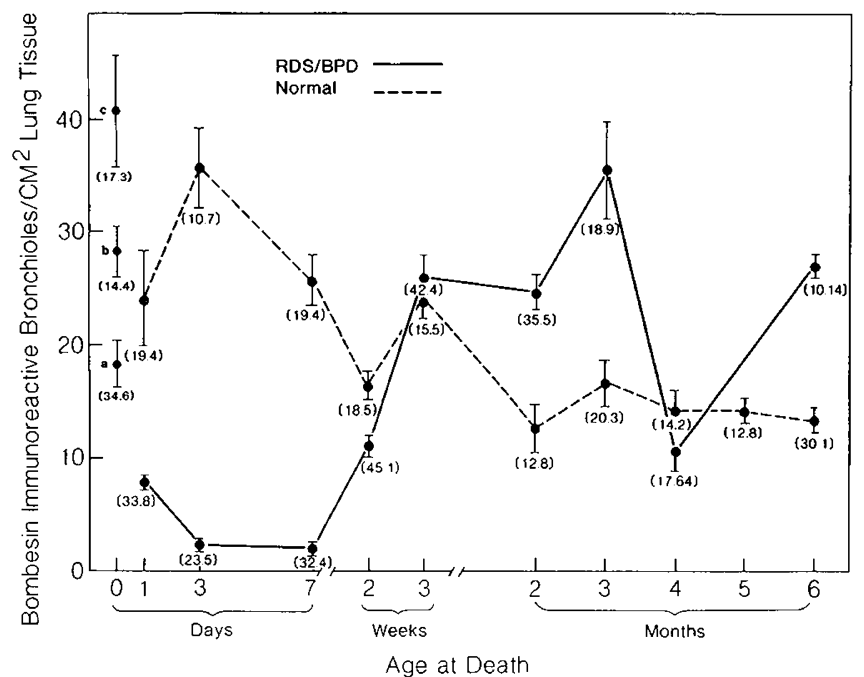

Fig. 4. Bombesin immunoreactive bronchioles $/ \mathrm{cm}^{2}$ of lung tissue in control infants - - - - and in infants with RSD/BPD-during the first 6 months of life ( \pm S.E.). $a$, second trimester control infants $b$, third trimester control infants $c$, term control infants () total number of $\mathrm{cm}^{2}$ quantitated. See Table $2 b$ for data on the gestational age, birth wt., and diagnosis at time of ealh of these control infants.

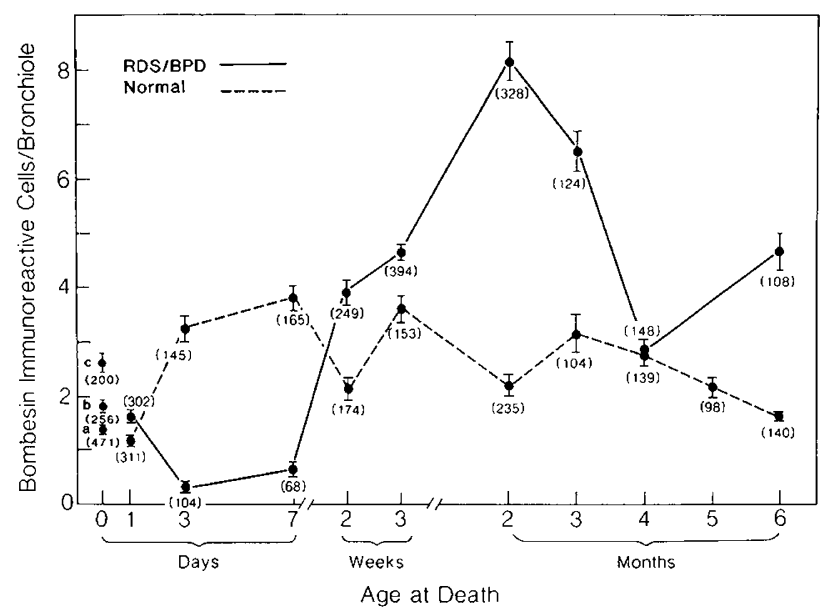

Fig. 5. Bombesin immunoreactive cells/bronchiole (true cross section, $90^{\circ}$ ) in control infants - - and in infants with RDS/BPD-during the first months of life ( \pm S.E.). $a$, second trimester control infants $b$, third trimester control infants $c$, term control infants ( ), total number of bronchioles quantitated. See Table $2 b$ for data on the gestational age, birth wt., and diagnosis at time of death of these control infants.

histochemical argyrophil staining, have been localized from the trachea through the alveolar ducts $(6,16,20)$. Collections of these cells (neuroepithelial bodies) are located predominantly at the bifurcation of airways. They are tall, nonciliated cylindrical cells which reach from the basement membranes to near the airway lumen. Neuroepithelial bodies $(20,23,30)$, as well as individual cells (23), are associated with one or more fenestrated capillaries lying just beneath their basal pole. Ultrastructurally, the cells are granulated with the polarity of secretion directed basally toward the capillary bed beneath the basement membrane $(5,12,23,33)$. Neuroepithelial bodies appear to be in close contact with nerve endings interpreted as being efferent and afferent in nature (14, $16,19,25,28)$. Innervation of individual PNEC has been rarely observed $(23,37)$. Three types of neuroendocrine cells can be discriminated in the fetus and in the newborn infant using granule morphology, whereas only one type can be identified in adults (4, $12,13)$. Not only is there less diversity in adult cell types, but the total number of PNEC dramatically decreases with age beginning shortly after birth $(15,24)$.
The nature of the secretory products of PNEC has received considerable attention. The first bioactive molecule recognized within PNEC was serotonin (18). The presence of this amine, together with other histochemical characteristics, established these particular cells as members of the APUD system $(26,27)$. However, not until bombesin immunoreactivity was localized to at least some of these cells was a peptide secretory product established $(4,36)$.

Bombesin was first isolated from amphibian skin glands of the genus Bombina (1). A bombesin-like peptide is present in both mammalian brain and gut derivatives $(3,7,34,35)$. This peptide is a physiologically active molecule, which affects smooth muscle contraction in a number of organ systems; stimulates gastric acid, cholecystokinin and exocrine pancreatic secretion; and centrally mediates alterations in thermoregulation and glucose homeostasis $(3,15,34,35)$. Mammalian peptides having bombesin immunoreactivity and physiologic effects appear to be larger than the amphibian peptide $(3,7,35)$. One of these peptides, porcine gastrin releasing peptide, a 27 amino-acid protein with physiologic effects very similar to bombesin, has been shown to have striking sequence homology to the C-terminal region of amphibian bombesin (22).

The physiologic role of these cells and their secretory products in neonatal lung is large unknown. Physiologic studies of PNEC have been limited to anatomic observation of the effect of certain stimuli on degranulation of these cells or an increase in cell number. Acute airway hypoxia and hypercapnia appear to be the most potent degranulating agents $(19,21,24)$. Pulmonary vascular hypoxemia has no effect on granule release (21); however, animals exposed to lifelong hypoxia (Peruvian rabbits) showed a dramatic increase in the number of PNEC (32). Morphologic changes induced in PNEC in response to hypoxia were similar to changes noted in carotid body receptor cells which exhibit degranulation in response to vascular hypoxemia $(10,24)$. In short, the neonatal lung possesses a large number of cells which have the following characteristics: (1) close proximity to both airways and vessels; (2) close proximity to the pulmonary innervation; (3) the ability to produce and secrete bioactive amines and peptides; (4) a close resemblance to other hypoxia-sensitive receptor cells. (5) degranulation during airway, but not during vascular hypoxic and hypercapnic states; and (6) Increase in number during prolonged hypoxia.

These data have led to speculation that these cells somehow influence vaso-and/or bronchomotor tone in response to alterations in airway gas composition. Despite this, the physiologic effects of these cells in the intact animal, or the role these cells may plan in human lung disease, remains entirely unexplored.

The present study highlights the marked changes seen in this cell population during acute and chronic neonatal lung disease, but clearly has a number of limitations. The study is retrospectively and relies on randomly selected tissue specimens from a patient population that could not be carefully controlled. Analysis does not take into account the effect on these cells of the acute or chronic disease processes which led to the death of control infants. The study also selects for only bombesin-immunoreactive pulmonary neuroendocrine cells, neglecting possible other populations of such cells. The quantitation techniques are subject to sampling error, because these cells may not be equally distributed among the various lobes of the lung. It is also extremely difficult to tell if the observed changes in PNEC's were due to alterations in the number of individual cells or size of bombesin-immunoreactive NEB. Because of the above limitations, interpretation of these data outside the general trends observed over the 6-month period are unjustified. Nevertheless, sampling at multiple points in time demonstrated that infants with HMD have fewer identifiable bombesin-immunoreactive PNEC compared to control infants, whereas infants with chronic BPD have more.

The methodology used cannot delineate either the morphologic bases, the specific cell population (individual PNEC or NEB), or the causal factors involved in the observed changes. Any decrease in cell number could be due to either increased intracellular peptide or cellular hyperplasia. The basic pathologic processes, 

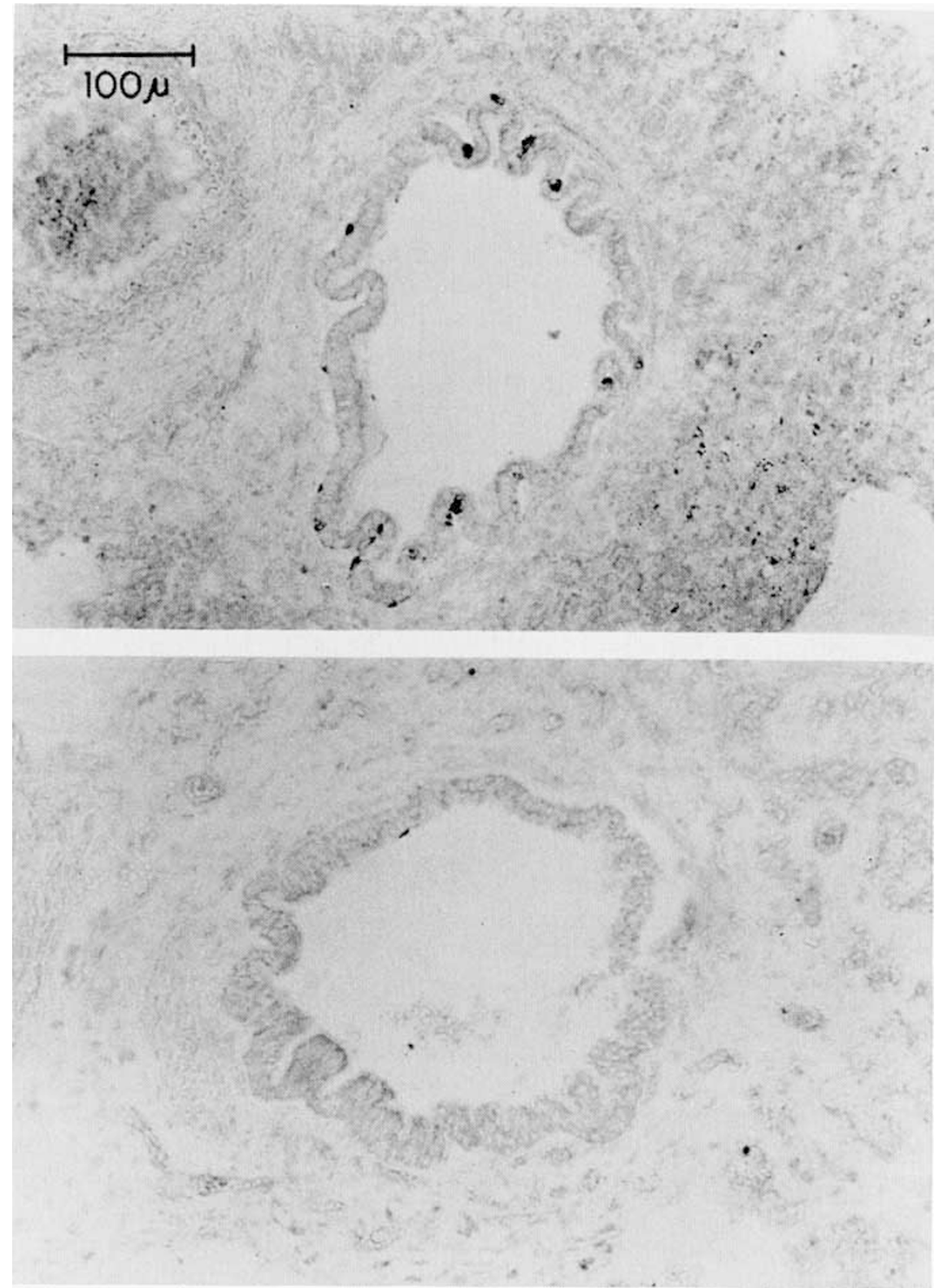

Fig. 6. Similar size bronchioles in a control infant (top) and in an infant with RDS (bottom). Both infants died at 3 days of age. The control infant demonstrates a large number of PNEC staining densely for bombesin immunoreactivity. No positive cells could be demonstrated in the infant with RDS. 


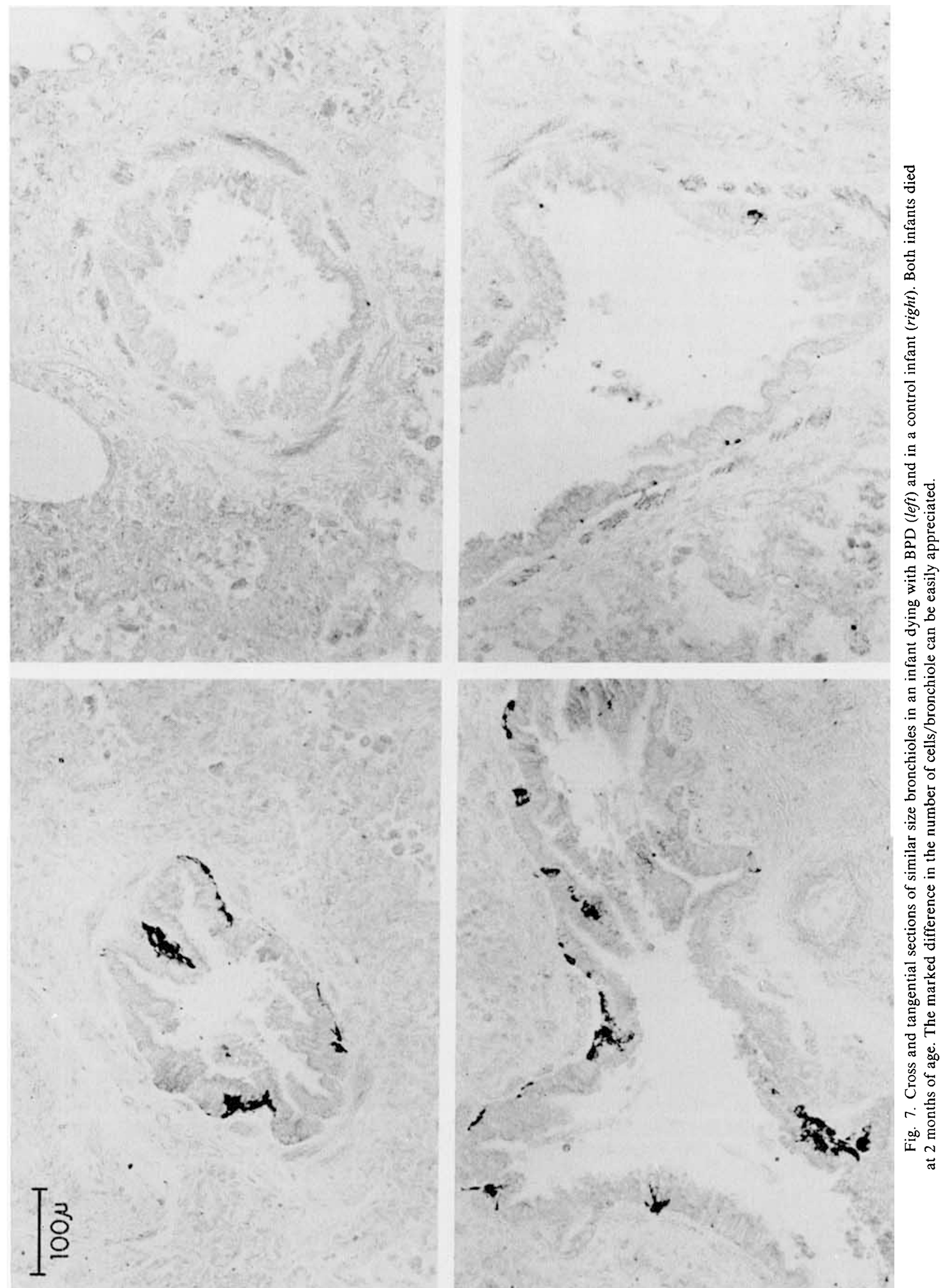


ventilator therapy, or oxygen toxicity could all be incriminated as etiologic agents responsible for the observed changes.

Increased pulmonary vascular and airway tone is known to influence the course of a number of neonatal diseases, including HMD (11) and BPD (9). These data do not prove that alterations in this cell population are related to changes noted in the airway and vascular resistance during neonatal lung disease. The study does identify, however, an entirely new area of potential investigation in these disease states.

\section{REFERENCES AND NOTES}

1. Anastasi, A., Erspamer, V., and Bucci, M.: Isolation and structure of bombesin and alytesin-two analogous peptides from the skin of European amphibians Bombina and Alytes. Experientia, 27: 166 (1971).

2. Becker, K., Monaghan, K., and Silva, O.: Immunocytochemical localization of calcitonin in Kultschitzky cells of human lung. Arch. Pathol. Lab. Med., 104: 196 (1980).

3. Brown, M., Allen, R., Villarreal, J., Rivier, J., and Vale, W.: Bombesin-like activity: radioimmunologic assessment in biological tissue. Life Sci., 23: 2721 (1978).

4. Capella, C.. Hage, E., Solcia, E., and Usellini, L.: Ultrastructural similarity of endocrine-like cells of the human lung and some related cells of the gut. Cell Tiss. Res., 186: 25 (1978).

5. Cutz, R., Chan, W., Wong, V., and Conen. P. E.: Ultrastructure and fluorescence histochemistry of endocrine (APUD) cells in tracheal mucosa of human and various animal species. Cell Tiss. Res., 158: 425 (1975).

6. Ericson, L. E., Håkanson, R., Larson, B., Owman, Ch., and Sundler, F.: Fluorescence and electron microscopy of amine-storing enterochromaffin-like cells in tracheal epithelium of mouse. Z. Zellforsch., 124: 532 (1972).

7. Erspamer, V., Falconieri Espamer, G., Melchiorri, P., and Negri, L.: Occurrence and polymorphism of bombesin-like peptides in the gastrointestinal tract of birds and mammals. Gut, 20: 1047 (1979).

8. Feyrter, F.: Über die argyrophile des Helle-Zellen-Systems in bronchialbaum des Menschen. Z. Mikro. Anat. Forsch. 61: 73-81 (1954).

9. Fouron, J-C., LeGuennec, J-C. Villemant, D., Bard, H., Perreault, G., and Davignon, A.: Value of echocardiography in assessing the outcome of bronchopulmonary dysplasia of the newborn. Pediatrics, 65: 529 (1980).

10. Frölich, F.: Die "Helle Zelle" der bronchialschleimaut and ihre beziehungen zum problem der chemoreceptoren. Frankfurt Z. Patho., 60: 517 (1949).

11. Goetzman, B. W., Sunshine, P.. Johnson, J. D., Wennberg, R. P., Hackel, A., Merten. D. F., Bartoletti, A. L., and Silverman, N. H.: Neonatal hypoxia and pulmonary vasospasm: response to tolazoline. J. Pediatr., 89: 617 (1976).

12. Hage, E.: Electron microscopic identification of several types of endocrine cells in the bronchial epithelium of human foetuses. Z. Zellforsch., 14I: 401 (1973).

13. Hage, E., Hage, J., and Juel, G.: Endocrine-like cells of the pulmonary epithelium of the human adult lung. Cell Tiss. Res., 178: 39 (1977).

14. Hung. K-S.. Hertweck, M. S., Hardy, J. D., and Loosli, C. G.: Ultrastructure of nerves and associated cells in bronchiolar epithelium of the mouse lung. $J$. Ultrastruct. Res., 43: 426 (1973).

15. Impicciatore. $M$. and Bertaccine, G.: The bronchoconstrictor action of the tetradecapeptide bombesin in the guinea pig. J. Pharm. Pharmac., 25: 872 (1973).

16. Lauweryns, J. M. and Peuskens. J. C.: Argyrophil (kinin and amine producing?) cells in human infant airway epithelium. Life Sci., 8: 577 (1969).

17. Lauweryns, J. M., Peuskens, J. C., and Cokelaere, M.: Argyrophil, fluorescent and granulated (peptide and amine producing?) AFG cells in human infant bronchial epithelium. Light and electron microscopic studies. Life Sci., 9: 417 (1970).

18. Lauweryns, J. M., Cokelaere, M., and Theunynck, P.: Serotonin producing neuroepithelial bodies in rabbit respiratory mucosa. Science, 180: 410 (1973).

19. Lauweryns, J. M. and Cokelaere, M.: Hypoxia-sensitive neuroepithelial bodies: Intrapulmonary secretory neuroreceptors, modulated by the CNS. Z. Zellforsch., 145: 521 (1973).

20. Lauweryns, J. M. and Goddeeris, P.: Neuroepithelial bodies in the human child and adult lung. Am. Rev. Resp. Dis., 111: 469 (1975).

21. Lauweryns, J. M., Cokelaere, M., and Theunynck, P.: Cross-circulation studies on the influence of hypoxia and hypoxemia on neuro-epithelial bodies in young rabbits. Cell Tiss. Res., 193: 373 (1978).

22. McDonald, T. J., Jörnvall, H., Nilsson, G., Vagne, M., Ghatei, M., Bloom S. R., and Mutt, V.: Characterization of a gastrin releasing peptide from porcine nonantral gastric tissue. Biochem. Biophys. Res. Comm., 90: 227 (1979).

23. McDougall, J.: Endocrine-like cells in the terminal bronchioles and saccules of human fetal lung: an ultrastructural study. Thorax, 33: 43 (1978).

24. Moosavi, H., Smith, P., and Heath, D.: The Feyrter cell in hypoxia. Thorax, 29: 729 (1973).

25. Morikawa, Y., Donahoe, P. K., and Hendren, W. H.: Cholinergic nerve development of fetal lung in vitro. J. Pediatr. Surg., 13: 653 (1978).

26. Pearse, A. F. G.: The cytochemistry and ultrastructure of polypeptide hormoneproducing cells of the APUD series and the embryologic, physiologic and pathologic implications of the concept. J. Histochem. Cytochem., 17: 303 (1969).

27. Pearse, A. G. E. and Takor-Takor, T.: Embryology of the diffuse endocrine system and its relationship to the common peptides. Fed. Proc., 38: 2288 (1979).

28. Rogers, D. C. and Haller, C. J.: Innervation and cytochemistry of the neuroepithelial bodies in the ciliated epithelium of the toad lung. (Budo marines) Cell Tiss. Res., 195: 395 (1978).

29. Rosan, R. C.: Hyaline membrane disease and a related spectrum of neonatal pneumopathies. Perspect. Pediatr. Path., 2: 15 (1975).

30. Sonstegard, K.. Wong, V., and Cutz, E.: Neuroepithelial bodies in organ cultures of fetal rabbit lung. Cell Tiss. Res., 199: 519 (1979)

31. Sternberger, L. A., Hardy, P. H., Cuculis, J. J., and Meyer, J. G.: The unlabeled antibody method of immunohistochemistry. Preparation and properties of soluble antigen-antibody complex (horseradish peroxidase-antithorseradish peroxidase) and its use in identification of spirochetes. J. Histochem. Cytochem., 18: 315 (1970).

32. Taylor, W.: Pulmonary argyrophil cells at high altitude. J. Path., 122: 137 (1977)

33. Terzakis, J. A., Sommers, S. C., and Andersson, B.: Neurosecretory appearing cells of human segmental bronchi. Lab. Invest., 26: 127 (1972).

34. Villarreal, J. A., and Brown, M. R.: Bombesin-like peptide in hypothalmus: chemical and immunological characterization. Life Sci., 23: 2729 (1978).

35. Walsh. J. H., Wong, H. C.. and Dockray, J. G.: Bombesin-like peptides in mammals. Fed. Proc., 38: 2315 (1979).

36. Wharton, J., Polak, J. M., Bloom, S. R., Ghatei, M. A., Solcia, E., Brown, M. R. and Pearse, A. G. E.: Bombesin-like immunoreactivity in the lung. Nature, 273: 769 (1978).

37. Wasano, K. and Yamamoto, T.: APUD-type recepto-secretory cells in the chicken lung. Cell Tiss. Res., 201: 197 (1979).

38. Requests for reprints should be addressed to: Dr. Dana E. Johnson, Box 211 , Mayo Memorial Building, University of Minnesota Hospital, 420 Delaware St. S.E. Minneapolis, MN 55455.

39. This research was supported by the American Lung Association.

40. Received for publication May 1, 1981.

41. Accepted for publication Aug 20. 1981 